\title{
PENERAPAN PEMBELAJARAN PROBLEM BASED LEARNING (PBL) UNTUK MENINGKATKAN HASIL BELAJAR MATEMATIKA SISWA KELAS IV SEKOLAH DASAR
}

\author{
Fida Rahmantika Hadi \\ FIP IKIP PGRI MADIUN \\ fidarahmantika88@ikippgrimadiun
}

\begin{abstract}
The purpose of this study was to describe the steps to the application of PBL learning to improve student learning outcomes in the material fractions. This research was a class act. In this study the data source was the teacher and the student. Data collection techniques used in this study consisted of (a) observation, (b) interviews, and (c) test. Methods of data analysis used in this research is descriptive qualitative and descriptive comparative. The steps of learning by PBL method are (1) the stage of cooperation where students formed into groups of 4-5 students, (2) the orientation of students to the problem, namely the provision of problems related to everyday life, (3) organization students to learn independently in a group, (4) guided inquiry groups using worksheets to gather the appropriate information, and (5) develop and present the results of discussions through presentations to the class. The resulting increases in students' mathematics learning of the results of the pre-action test 71.31 and increased in the first cycle to 75.78, on the second cycle increased by 82.63 .
\end{abstract}

Keywords: Problem based learning (PBL), Students Achievement, Mathematic

\section{PENDAHULUAN}

Peningkatan kualitas pendidikan merupakan hal yang tidak akan habis dibicarakan dan diupayakan. Salah satu upaya peningkatan kualitas pendidikan tersebut adalah mengubah paradigma pendidikan khususnya di sekolah dasar (SD). Selama ini pengajaran hanya berpusat pada guru saja untuk itu para guru dituntut agar lebih kreatif dalam mengembangkan pembelajaran. Siswa diharapkan dapat berprestasi melalui kegiatan-kegiatan nyata yang menyenangkan dan mampu mengembangkan potensi siswa secara optimal.

Dalam proses pembelajaran di SD Taman 3, siswa masih berpendapat bahwa mata pelajaran matematika adalah mata pelajaran yang sulit. Berdasarkan observasi langsung yang dilaksanakan tanggal 3 Oktober 2016, pada setiap mata pelajaran matematika kelas IV guru lebih sering menggunakan metode ceramah, tanyajawab, dan penugasan. Serta model pembelajarannnya masih bersifat konvensional. Guru juga memaparkan bahwa ketika mengajar jarang sekali menerapkan model pembelajaran yang bermacam-macam. Hal ini disebabkan target terselesaikannya seluruh materi selama satu semester yang harus terpenuhi. Oleh karena itu siswa hanya terpaku pada guru dan buku saja. Mereka kurang termotivasi dalam belajar dan belum belajar secara aktif. Sehingga mereka belum menemukan hal yang menarik dari matematika. Metode ini akan membuat siswa cenderung pasif dalam mengikuti kegiatan pembelajaran. Peran guru lebih dominan dibanding peran siswa.

Berdasarkan permasalahan yang dihadapi siswa kelas IV SD Taman 3 dibutuhkan model pembelajaran yang dapat mengembangkan dan menggali pengetahuan siswa secara maksimal. Selain itu juga dapat mengaktifkan 
siswa untuk belajar bersama-sama sehingga siswa lebih mudah untuk memahami konsep yang diajarkan dan memiliki kemampuan mengkomunikasikan ide yang dimiliki baik secara lisan maupun tulisan. Salah satu model pembelajaran yang sesuai dalam menyelesaikan permasalahan di atas adalah model pembelajaran Problem Based Learning (PBL). Menurut Arends (2008: 41), PBL adalah pembelajaran yang menyuguhkan berbagai situasi masalah yang autentik dan bermakna kepada siswa, yang dapat berfungsi sebagai batu loncatan untuk invetigasi dan penyelidikan. Sedangkan Sanjaya (2009: 214) juga berpendapat bahwa PBL dapat diartikan sebagai rangkaian aktivitas pembelajaran yang menekankan pada proses penyelesaian masalah yang dihadapi secara ilmiah.

Dari pendapat di atas dapat disimpulkan bahwa pengertian PBL adalah pembelajaran yang memberikan masalah kepada siswa dan siswa diharapkan untuk menyelesaikan masalah tersebut dengan melaksanakan pembelajaran yang aktif. Sehingga pada pembelajaran ini siswa yang selalu aktif, guru hanya sebagai fasilitator.

Masalah yang diberikan kepada siswa dalam metode PBL merupakan masalah yang berkaitan dengan kehidupan seharihari. Pemberian masalah dalam konteks dunia nyata ini bertujuan agar siswa mampu membangun sendiri pengetahuan baru yang diterimanya. Hal ini sesuai dengan pendapat Trianto (2007:67) bahwa pembelajaran berdasarkan masalah menyajikan situasi masalah yang otentik dan bermakna kepada siswa sehingga dapat memberikan kemudahan kepada mereka untuk melakukan penyelidikan dan inkuiri. Melalui permasalahan yang diberikan, siswa akan berusaha menyelesaikan masalah tersebut berdasarkan pengetahuan yang telah mereka miliki sebelumnya sehingga siswa mampu menemukan keterkaitan antara materi terdahulu dengan materi baru yang sedang mereka pelajari.

Menurut Amir (2009: 12), ciri-ciri atau karakteristik PBL antara lain: 1) pembelajaran diawali dengan pemberian masalah; 2) siswa berkelompok secara aktif merumuskan masalah; 3) mempelajari dan mencari sendiri materi yang ber-hubungan dengan masalah serta melaporkan solusinya.

Sugiyanto (2008: 140) mengemukakan ada 5 tahapan yang harus dilaksanakan dalam PBL, yaitu: 1) Memberikan orientasi tentang per-masalahannya kepada siswa. 2) Mengorganisasikan siswa untuk meneliti. 3) Membantu investigasi mandiri dan kelompok. 4) Mengembangkan dan mempresentasikan hasil. 5) Menganalisis dan mengevaluasi proses mengatasi masalah.

Sanjaya (2009: 220) menyebutkan keunggulan PBL antara lain: 1) PBL merupakan teknik yang cukup bagus untuk lebih memahami pelajaran; 2) PBL dapat menantang kemampuan siswa serta memberikan ke puasan untuk menemukan pengetahuan baru bagi siswa; 3) PBL dapat meningkatkan aktivitas pembelajaran; 4) melalui PBL bisa memperlihatkan kepada siswa setiap mata pelajaran (matematika, IPA, dan lain sebagainya), pada dasarnya merupakan cara berpikir, dan sesuatu yang harus dimengerti oleh siswa, bukan hanya sekadar belajar dari guru atau buku-buku saja; 5) PBL dianggap lebih menyenangkan dan disukai siswa; 6) PBL dapat mengembangkan kemampuan berpikir kritis; 7) PBL dapat memberikan kesempatan kepada siswa untuk mengaplikasikan pengetahuan yang mereka miliki dalam dunia nyata; 8) PBL dapat mengem-bangkan minat siswa untuk belajar 
secara terus menerus sekalipun belajar pada pendidikan formal telah berakhir.

Berdasarkan uraian tersebut diatas, dapat dirumuskan suatu masalah yang menjadi fokus perbaikan pembelajaran, antara lain sebagai berikut: Bagaimanakah penerapan PBL dalam meningkatkan proses pembelajaran matematika siswa kelas IV SD Taman 3 Tahun Ajaran 2016/ 2017? Apakah penerapan model PBL dapat meningkatkan hasil belajar matematika siswa kelas IV Taman 3 Tahun Ajaran 2016/ 2017? Tujuan dari penelitian ini adalah untuk mendiskripsikan penerapan PBL dalam meningkatkan proses pembelajaranmatematika siswa kelas IV SD Taman 3 Tahun Ajaran 2016/ 2017 dan untuk mengetahui penerapan model PBL dapat meningkatkan hasil belajarmatematika siswa kelas IV SD Taman 3 Tahun Ajaran 2016/ 2017.

\section{METODE PENELITIAN}

Penelitian ini merupakan penelitian tindakan kelas. Menurut Sanjaya (2012: 26) penelitian tindakan kelas diartikan sebagai proses pengkajian masalah pembelajaran di dalam kelas melalui refleksi diri dalam upaya untuk memecahkan masalah tersebut dengan cara melalui berbagai tindakaan yang terencana dalam situasi nyata serta menganalisis setiap pengaruh dari perlakuan tersebut. Data adalah pencatatan peneliti, baik berupa fakta ataupun angka.

Data yang dikumpulkan dalam penelitian ini berupa fakta dan informasi mengenai pembelajaran matematika model PBL di kelas IV SD.Arikunto (2006:129) menyatakan sumber data dalam penelitian adalah subyek dari mana data dapat diperoleh. Pada penelitian ini sumber datanya adalah guru dan siswa. Guru bertindak sebagai informan, yaitu orang yang memberikan informasi tentang pembelajaran matematika pada siswa kelas IV SD. Siswa bertindak sebagai subjek, yaitu seseorang yang melaksanakan kegiatan dan diberi tindakan. Sasaran yang ingin dicapai pada penelitian ini adalah model pembelajaran PBL mampu meningkatkan hasil pembelajaran matematika siswa kelas IV SD. Teknik pengumpulan data yang digunakan pada penelitian ini terdiri dari (a) observasi, (b) wawancara, dan (c) tes. Setelah melakukan observasi, wawancara, pemberian tugas, maka langkah berikutnya adalah memaparkan dan menganalisis data. Menurut Wiyono dan Burhannuddin (2007: 90) analisis data adalah proses penyusunan data agar bisa ditafsirkan dan disimpulkan.

Metode analisis data yang yang digunakan pada penelitian ini adalah deskriptif kualitatif dan deskriptif komparatif. Analisis data deskriptif kualitatif akan digunakan untuk mengalisis data verbal, yaitu data hasil pengamatan pembelajaran matematika siswa kelas IV SD dengan menggunanakan model PBL. Analisis data deskriptif komparatif untuk data kuantitatif, yakni dengan membandingkan hasil antarsiklus.

Prosedur penelitian ini adalah setiap siklus terdiri dari empat tahapan yaitu perencanaan, pelaksanaan tindakan, observasi, dan refleksi. Berdasarkan hasil refleksi siklus I ini akan ditentukan berlanjut ke siklus II atau tidak. Jika berlanjut ke siklus II maka pada siklus II akan dilakukan sesuai dengan langkah-langkah dari siklus I, begitu seterusnya. Indikator keberhasilan tindakan meningkatkan hasil belajar siswa dengan penggunakan model PBL adalah ada jumlah siswa yang mengalami ketuntasan belajar sekurang-kurangnya $75 \%$ dari jumlah siswa dalam kelas tersebut. 


\section{HASIL DAN PEMBAHASAN}

Untuk mengetahui kondisi di lapangandilakukan observasi pra tindakanmelaluipengamatan dan tes. Dari pengamatan yang dilakukan diketahui bahwa siswa kurangberminat mengikuti pembelajaran matematika. Siswa masih menganggap bahwa pembelajaran matematika merupakan pelajaran yang sulit. Selain itu siswa juga tidak aktif dalam proses pembelajaran. Hasil tes pada pratindakan dapat dilihat dalam tabel 1.

Tabel 1. Data Nilai Pra-tindakan

\begin{tabular}{|c|c|c|c|}
\hline No & Nilai & $\begin{array}{c}\text { Jumlah } \\
\text { Siswa }\end{array}$ & $\begin{array}{l}\text { Total } \\
\text { Nilai }\end{array}$ \\
\hline 1 & 55 & 1 & 55 \\
\hline 2 & 60 & 4 & 240 \\
\hline 3 & 65 & 2 & 130 \\
\hline 4 & 70 & 2 & 140 \\
\hline 5 & 75 & 3 & 225 \\
\hline 6 & 80 & 6 & 480 \\
\hline 7 & 85 & 1 & 85 \\
\hline \multicolumn{2}{|c|}{ Jumlah } & & 1335 \\
\hline \multicolumn{2}{|c|}{ Rata-rata } & & 71,31 \\
\hline
\end{tabular}

Berdasarkan hasil pratindakan, dapat dilihat bahwa siswa yang belum mencapai KKM sebanyak 9 siswa dan siswa yang sudah menacapai nilai KKM sebanyak 10 siswa. Sehingga dari hasil di atas dapat diambil kesimpulan bahwa hasil tes siswa masih rendah, hanya sebesar 71,31. Tahap perencanaan tindakan di siklus I dimulai dari penemuan masalah yang dilanjutkan dengan merancang tindakan yang akan dilakukan. Hasil perencanaan siklus I yaitu (a) merancang sekenario pembelajaran, (b) peneliti menyusun RPP, (c) peneliti menyiapkan instrumen penilaian dan catatan lapangan pelaksanaan pembelajaran matematika dengan menggunakan model PBL.
Tahap-tahap pelaksanaan pembelajaran pada siklus I yang diterapkan peneliti sebagai berikut:

1. Orientasi siswa kepada masalah, Pada tahap ini peneliti menyampaikan tujuan pembelajaran dan mengaitkan dengan materi prasyarat melalui tanya jawab langsung kepada siswa. Peneliti memberikan motivasi kepada siswa agar mampu bekerja sama dengan baik dalam satu kelompok. Setelah itu pemberian masalah kepada setiap kelompok. Penyajian masalah ini berupa soal yang terdapat dalam LKS yang telah disiapkan oleh peneliti. Masalah yang dibuat disesuaikan dengan tujuan pembelajaran yang ingin dicapai.

2. Mengorganisasikan siswa untuk belajar Pada tahap ini peneliti membagi siswa ke dalam kelompok kecil yang beranggotakan 4-5 orang siswa. Setelah kelompok terbentuk dan masingmasing siswa duduk sesuai dengan kelompoknya, peneliti membagikan tugas belajar berupa LKS yang berisi masalah-masalah yang harus diselesaikan oleh siswa melalui diskusi kelompok.

3. Membimbing kelompok belajar dan bekerja Pada tahap ini peneliti membimbing siswa dalam pengerjaan LKS. Peneliti berkeliling ke tiap-tiap kelompok untuk menanyakan apakah ada bagian yang dirasa sulit atau membingungkan. Jika siswa mengalami kesulitan, peneliti bertindak sebagai pengarah dengan memberi arahan atau pertanyaan pancingan sehingga siswa bisa menemukan sendiri jawaban dari pertanyaan yang diberikan. Peneliti meminta kepada setiap siswa untuk 
berperan aktif dalam kegiatan diskusi kelompok.

4. Mengembangkan dan menyajikan hasil karya Pada tahap ini peneliti meminta siswa untuk melaporkan atau mempresentasikan hasil diskusi mereka di depan kelas. Peneliti bertindak sebagai pengatur jalannya diskusi. Peranan guru dalam kegiatan ini sangat penting. Guru bertindak sebagai pengatur jalannya diskusi kelas. 5 . Menganalisis dan mengevaluasi proses pemecahan masalah Pada tahap ini peneliti bersama siswa mendiskusikan jawaban yang tepat dari pertanyaan yang tercantum dalam LKS. Selanjutnya peneliti bersama siswa juga membuat kesimpulan terhadap kegaiatan pembelajaran yang telah dilakukan.

Berdasarkan hasil pengamatan pada saat berlangsungnya pembelajaran pada siklus I, hasil proses dan hasil tes mengalami peningkatan. Dapat dilihat dalam tabel 2.

Tabel 2. Data Proses Pembelajaran Siklus 1

\begin{tabular}{cccc}
\hline & & \multicolumn{2}{c}{ Jumlah Siswa } \\
\cline { 3 - 4 } No & Nilai & $\begin{array}{c}\text { Presentasi } \\
\text { Hasil Diskusi } \\
\text { Kelompok }\end{array}$ & $\begin{array}{c}\text { Keaktifan Dalam } \\
\text { Pembelajaran Di } \\
\text { Kelompok }\end{array}$ \\
\hline 1 & 60 & 4 & 7 \\
2 & 65 & 8 & 5 \\
3 & 70 & 6 & 5 \\
4 & 75 & 1 & 3 \\
5 & 80 & 1 & 0 \\
\hline \multicolumn{2}{c}{ Jumlah } & 1335 & 1320 \\
Rata-rata & 70,26 & 69,47 \\
\hline
\end{tabular}

Berdasarkan data dalam proses pembelajaran pada siklus I dalam tabel 2 dan 3 , siswa seringkali merasa gugup atau malu ketika diminta untuk presentasi di depan kelas. Hal ini disebabkan karena siswa belum terbiasa melakukan kegiatan presentasi selama kegiatan pembelajaran. Dalam kegiatan diskusi bersama kelompok siswa juga masih kurang aktif. Berdasarkan hasil tes dari 19 siswa kelas IV SD Taman 3 yang mengikuti tes pada siklus I terdapat 12 siswa yang mencapai nilaiKKM. Sedangkan siswa yang belum mencapai nilai KKM sebanyak 7 siswa. Berdasarkan hasil siklus I dapat diketahui bahwa indikator pencapaian sudah tercapai, akan tetapi kurang maksimal sehingga diperlukan lagi perbaikan yang akan dilaksanakan pada siklus II.

Tabel 3. Data Hasil Tes Siklus-I

\begin{tabular}{|c|c|c|c|}
\hline No & Nilai & $\begin{array}{c}\text { Jumlah } \\
\text { Siswa }\end{array}$ & Total Nilai \\
\hline 1 & 60 & 1 & 60 \\
\hline 2 & 65 & 4 & 260 \\
\hline 3 & 70 & 2 & 140 \\
\hline 4 & 75 & 2 & 150 \\
\hline 5 & 80 & 5 & 400 \\
\hline 6 & 85 & 4 & 340 \\
\hline 7 & 90 & 1 & 90 \\
\hline \multicolumn{2}{|c|}{ Jumlah } & & 1440 \\
\hline \multicolumn{2}{|c|}{ Rata-rata } & & 75,78 \\
\hline
\end{tabular}

Rencana tindakan siklus II hampir sama dengan perencanaan pada siklus I. Akan tetapi, pelaksanaan tindakan siklus II dilakukan dengan memperhatikan hasil refleksi pada siklus I. Hasil perencanaan siklus I yaitu (a) merancang sekenario pembelajaran, (b) peneliti menyusun RPP, (c) peneliti menyiapkan instrumen penilaian dan catatan lapangan pelaksanaan pembelajaran keterampilan berbicara. Tahap-tahap pembelajaran siklus II, dilakukan setelah adanya revisi berdasarkan hasil refleksi dari siklus I. Perbaikan yang dilakukan pada siklus II ini yaitu penyajian masalah pada LKS dibuat dengan menggunakan gambar. Ini diharapkan siswa dapat menyelesaikan masalah lebih baik. Berdasarkan hasil 
pengamatanpada saat berlangsungnya pembelajaran pada siklus II, hasil proses dan hasil tes mengalami peningkatan. Dapat dilihat di dalam tabel 4 dan 5 .

Tabel 4. Data Proses Pembelajaran Siklus-II

\begin{tabular}{cccc}
\hline & & \multicolumn{2}{c}{ Jumlah Siswa } \\
\cline { 3 - 4 } No & Nilai & $\begin{array}{c}\text { Presentasi } \\
\text { Hasil Diskusi } \\
\text { Kelompok }\end{array}$ & $\begin{array}{c}\text { Keaktifan Dalam } \\
\text { Pembelajaran Di } \\
\text { Kelompok }\end{array}$ \\
\hline 1 & 65 & 2 & 2 \\
2 & 70 & 5 & 3 \\
3 & 75 & 5 & 5 \\
4 & 80 & 5 & 7 \\
5 & 85 & 2 & 3 \\
\hline Jumlah & 1425 & 1450 \\
Rata-rata & 75 & 76,32 \\
\hline
\end{tabular}

Tabel 5. Data Hasil Tes Siklus-II

\begin{tabular}{cccc}
\hline No & Nilai & $\begin{array}{c}\text { Jumlah } \\
\text { Siswa }\end{array}$ & Total Nilai \\
\hline 1 & 75 & 4 & 300 \\
2 & 80 & 6 & 480 \\
3 & 85 & 5 & 425 \\
4 & 90 & 3 & 270 \\
5 & 95 & 1 & 95 \\
\hline \multicolumn{2}{c}{ Jumlah } & & 1570 \\
Rata-rata & & 82,63 \\
\hline
\end{tabular}

Berdasarkan data dalam proses pembelajaran pada siklus II, siswa sudah berkuranggugupnya ketika diminta untuk presentasi di depan kelas. Siswa sudah berani menyampaikan hasil diskusi karena sudah pernah sebelumnya. Siswa juga sudah banyak yang aktif dalam kegiatan diskusi bersama kelompok.

Berdasar hasil tes dari 19 siswa kelas IV SD Taman 3 yangmengikuti tesakhir pada siklus II semua siswa sudah mencapai nilai di atas KKM. Jadi karena kriteria yang diterapkan peneliti telah tercapai padasiklus II yaitu semua siswa sudah mencapai nilai KKM maka penelitian ini dihentikan pada siklus II.
Pada pra tindakan ada banyak permasalahan dalam proses pembelajaran matematika. Masih banyak siswa yang mengalami kesulitan dalam hal menyelesaikan masalah. Selain itu siswa juga sulit mengungkapkan hasil diskusi bersama kelompoknya. Siswa cenderung malu dan kurang percaya diri karena belum terbiasa berbicara di depan umum. Minat siswa terhadap pembelajaran matematika juga rendah, hal itu karena siswa merasa bosan dengan pembelajaran. Hal itu menyebabkan hasil pembelajaran matematika siswa masih rendah. Ini dilihat dari nilai rata-rata pada hasil pratindakan adalah 71,31 yang masih di bawah KKM. Oleh sebab itu, diperlukan perbaikan pembelajaran dengan menggunakan model pembelajaran yang inovatif. Salah satu model pembelajaran yang inovatif yaitu model PBL.

Pada siklus I, aktivitas pembelajaran siswa kelas IV dalam mengikuti pembelajaran menggunakan model PBLsudah berjalan sesuai dengan rencana. Proses pembelajaran berjalan baik, siswa menjadi lebih antusias mengikuti pembelajaran. Siswa lebih berminat dalam mengikuti pembelajaran matematika. Nilai siswa dalam hal presentasi hasil diskusi dengan kelompok pada siklus satu memiliki rata-rata 70,26, sedangkan keaktifan siswa 69,47. Untuk data hasil tes nilai rata-rata pada siklus I adalah 75,78. Jika dibandingkan dengan rata-rata hasil tes sebelum tindakan maka rata-rata hasil tes siswa pada siklus I meningkat sebesar 4,47 poin dari 71,31 menjadi 75,78.

Pada siklus II aktivitas pembelajaran siswa kelas IV dalam pembelajaran menggunakan model PBL bertambah lebih baik lagi dari siklus I. Siswa lebih antusias dalam mengikuti pembelajaran. Hal itu juga menunjukkan rasa malu siswa untuk berbicara 
di depan kelas sudah berkurang. Siswa juga sudah aktif dalam proses pembelajaran. Nilai siswa dalam hal presentasi hasil diskusi dengan kelompok pada siklus satu memiliki rata-rata 75, sedangkan keaktifan siswa 76,32. Hal itu membuktikan bahwa kualitas pembelajaran dari pra tindakan, siklus I, hingga siklus II mengalami peningkatan. Dari sebelum tindakan hingga siklus II, kegiatan proses pembelajaran mengalami perubahan ke arah yang lebih baik. Kegiatan pembelajaran menjadi lebih menarik dan bermakna. Untuk data hasil tes pada siklus II adalah 82,63. Jika dibandingkan dengan rata-rata hasil tes pada siklus I maka ratarata hasil tes siswa pada siklus II meningkat sebesar 6,85 poin dari 75,78 menjadi 82,63. Pada siklus II ini, tidak ada siswa yang mendapatkan nilai di bawah KKM. Semua siswa mendapatkan nilai tuntas. Hal tersebut menunjukkan bahwa model pembelajaran PBL dapat meningkatkan hasil belajar matematika pada siswa.

\section{SIMPULAN}

Berdasarkan hasil penelitian dan pembahasan dapat disimpulkan sebagai berikut.

1. Langkah-langkah Problem Based Learning (PBL) yang dapat meningkatkan hasil belajar matematika siswa kelas IV yaitu: memberikan masalah dalam bentuk LKS pada masingmasing siswa, membagi siswa dalam kelompok, membimbing siswa baik secara individu maupun kelompok dalam upaya pengerjaan LKS, meminta siswa untuk mempresentasikan hasil diskusinya di depan kelas, dan mendiskusikan jawaban yang tepat dari pertanyaan yang tercantum dalam LKS serta membuat kesimpulan.

2. Penerapan pembelajaran Problem Based Learning (PBL) dapat meningkatkan hasil belajar siswa kelas pada materi pecahan.

Hasil tes siswa dari pra tindakan hingga siklus II sudah mengalami peningkatan. Pada pra tindakan nilai rata-rata kelas 71,31 dan siswa yang mendapatkan nilai belum tuntas ada 47,4\%. Pada siklus I sudah mengalami peningkatan. Nilai rata-rata kelas naik menjadi 75,78 . Siswa yang belum tuntas ada $36,8 \%$. Siklus II sudah mengalami peningkatan dari siklus I. Nilai rata-rata kelas 82,63 dan semua siswa sudah mendapatkan nilai tuntas. Hal tersebut menunjukkan bahwa model pembelajaran PBL dapat meningkatkan hasil belajar matematika pada siswa kelas IV SD Taman 3.

\section{DAFTAR PUSTAKA}

Amir, M. Taufiq. 2008. Inovasi Pendidikan Melalui Problem Based Learning. Jakarta: Kencana.

Arends, Richard I. 2008. Learning to Teach. Yogyakarta: Pustaka Pelajar

Arikunto, Suharsimi. 2006. Prosedur Penelitian: Suatu Pendekatan Praktik. Jakarta: PT Rineka Cipta.

Sanjaya, Wina. 2009. Strategi Pembelajaran Berorientasi Standar Proses Pendidikan. Jakarta: Kencana Prenada Media Group . 
'Sugiyanto. 2008. Model-model Pembelajaran Inovatif. Surakarta: Panitia Sertifikasi Guru Rayon 13.

Trianto. 2007. Model-Model Pembelajaran Inovatif Berorientasi Konstruktivis. Jakarta: Prestasi Pustaka.

Wiyono, Bambang Budi dan Burhanuddin. 2007. Metodologi Penelitian (Pendekatan Kuantiatif, Kualitatif, dan Action Research). Malang: FIP Universitas Negeri Malang. 